LOCAL WISDOM, 12 (2): 111-123, 2020
Local Wisdom Scientific Online Journal
ISSN: 2086-3764

\title{
Causal Factors of the Locality Disappearance of Kelayan's Riverside Settlement in Banjarmasin
}

\author{
Annisa Yuniar \\ Departement Architecture, University of Nahdlatul Ulama Kalimantan Selatan \\ Corresponding Author: annisayuniar90@gmail.com
}

\begin{tabular}{|c|c|}
\hline \multirow[b]{2}{*}{$\begin{array}{l}\text { Keywords: } \\
\text { Slum Area, Riverside, } \\
\text { Banjarmasin }\end{array}$} & Abstract \\
\hline & $\begin{array}{l}\text { Banjarmasin is the capital city of South Borneo province which } \\
\text { known as city of one thousand rivers. But nowadays the expansion of } \\
\text { riverside localities of Banjarmasin are uncontrolled and almost all of } \\
\text { the areas are slums. Slum areas riverside commonly formed by many } \\
\text { unorganized building that exceed the river's borderline and the } \\
\text { riverside localities' behaviors such as throwing the garbage and } \\
\text { taking a bath at the river. Our government now focused on handling } \\
\text { program to overcome the expansion of riverside slum areas by } 100-0- \\
100 \text { movement which means } 100 \% \text { for the water service, } 0 \% \text { for slum } \\
\text { area expansion and } 100 \% \text { for sanitation accessibility. Data analysis } \\
\text { was descriptive qualitative method with case study approach. Data } \\
\text { were collected with observation, questionnaire and interview. } \\
\text { Sampling technique was simple random sampling for sample in } \\
\text { research location. Result shows that the dominant factors of slum } \\
\text { areas at Kelayan riverside are unorganized buildings, uncontrolled } \\
\text { garbage and waste management. }\end{array}$ \\
\hline $\begin{array}{l}\text { DOI:https:// doi.org/ } \\
\text { @ } 2017 \text { The Authors. }\end{array}$ & $\begin{array}{lllll}.26905 / \text { lw.v12i2.4166 } & \text { Article History } & \text { Received } & : & \text { May 6, 2020 } \\
\text { iblished by GKAK UNMER Malang } & & \text { Accepted } & : & \text { June 26, 2020 } \\
& & \text { Published } & : & \text { July 15, 2020 }\end{array}$ \\
\hline
\end{tabular}

\section{INTRODUCTION}

Banjarmasin City is well known as a thousand rivers. According to its history, the first idea of Banjarmasin has formed from the riverside settlement. The people that live in such time was establishing their houses near the riverside, because of their activity that tend to follow the rivers area. The houses that stay in the riverside were aligned to the shape of the river, the settlement of riverside of Banjarmasin is actually the settlement that lives accordingly to the characters and locality element (Mentayani, 2016). The locality characters are pictured in the river custom and the wetland structures. This settlement's pattern is the utmost concern to the ecosystem balance, because it is still consider the river as the natural resources (Dahliani, 2012). However, nowadays, the riverside settlement of Banjarmasin city has uncontrollable condition. The riverside house that originally had characteristics of a vernacular architecture, has now begun to change. According to Afdholy (2019) addition of space function, the change of foundation structure and material, 
economy and community knowledge about recent technology are the development factors of vernacular houses in the riverside of Banjarmasin.

And almost all the region of riverside in every each of the districts is categorized as the slums area. At first, the riverside area was the locality characteristic of Banjarmasin city, otherwise it is becoming the bad image for the city because of uncountable slums area in the land or in the riversides.

From the phenomenon that occur on those settlement area of Banjarmasin, the government of Banjarmasin has released the regulation about Slums that function to control and eliminate the growing of slums in Banjarmasin city. According to the Slum's regulation of Banjarmasin year 2015, Banjarmasin has the slum area around 549,7 hectares categorized as small slum, medium, and heavy. The slum area of Banjarmasin is divided into 2 typologies, such as slum area in central of the city with 320.26 hectares wide and slum area in the riverside with 229.44 hectares or around $41.74 \%$ from the total of whole slum areas.

The slum area of the riverside is commonly shaped because of the disorganized establishment and violated the border line of riverside also the habit of the people that live on the riverside such as thrashing on the river and doing the activity such shower, and defecate in the river. If spotted from the map of slum area of Banjarmasin, predominantly the area would be on the southern area of Banjarmasin and that is located on the Kelayan's river that passes several districts, such as Kelayan Luar, Kelayan Barat, Kelayan Dalam, Kelayan Tengah and Murung Raya districts. The river is the life source for the people that live in the riverside of Kelayan. There are many activities in the river from showering, cleaning, fishing until the transportation for the merchants as their way to mobility and station of pick-ups the passengers on the harbour. The more it is growing population of the people, the more the river life is getting recessive. The pattern of settlement that align to the riverside becoming the river as the back of their home and polluting the river of Kelayan of south Banjarmasin disctrict. Based on the backgrounds explained above, it can be drawn the factors that caused the slum on the Kelayan riversides of Banjarmasin city.

According to Budiharjo in Heryati (2008) the slum areas is the low-quality environment and uninhabitable, the character is located on the area that adjustable to the regulation of layout, building density that is very high in limited width, diseases and social prone, also the low quality of the establishment, zero availability of environmental facilities and endangering the ecosystem and the life of the society.

Kelayan's river in the regional regulation number 5 about the RTRW of Banjarmasin (2013) mentioned as the protection areas that gives the protection to underline areas such as the water infiltration areas. As the water infiltration area, according to clause number 44 it is not allowed to any of activity of farming that causes the disruption to the river function and the settlement that has already established inside the water infiltration area before the regulation has legally stamped is allowed, however it is not allowed to increase more establishment. Hence, the settlement area is not allowed to be established in the protection areas.

\section{RESEARCH'S LOCATION AND METHOD}

The research is conducted in the city of Banjarmasin, South Kalimantan Province. In the Statistics of Banjarmasin year 2016, Kelayan's river has the length of 3.227 meters and 26 
meters width. Kelayan's river geographically is located in the southern of Banjarmasin city. Kelayan Barat, Kelayan Luar, Kelayan Tengah, Kelayan Dalam and Murung Raya are the districts that passed by and used the Kelayan's river as the administrative boundaries. In the following map is the administration Kelayan's riverside and the deployment of slum area map:

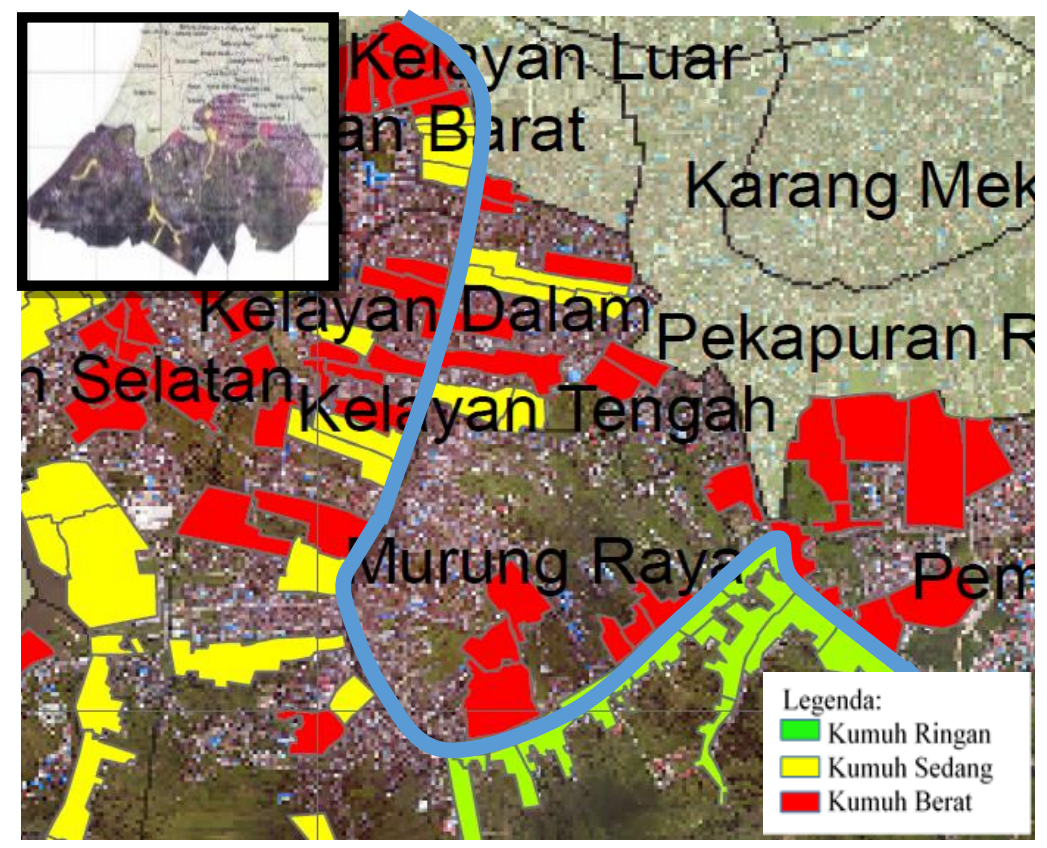

Figure 1. Slum area location map of Kelayan's Riverside

To support the analysis, it is needed the primary data. This phase will be conducted by the data collecting in accordance to the material coverage. The method that used in the secondary data collection is to collect the data that acquired from the related agencies or from the necessary literatures. In addition, the primary data is conducted through the field observation.

Table 1. The field data observation type

\begin{tabular}{|c|c|c|c|}
\hline Data type & $\begin{array}{l}\text { Procedure to collect the } \\
\text { data }\end{array}$ & Data usage & Output \\
\hline $\begin{array}{l}\text { Physical } \\
\text { condition of } \\
\text { Kelayan's } \\
\text { riverside }\end{array}$ & $\begin{array}{l}\text { Observing the physical } \\
\text { condition based on the slum } \\
\text { indicators: } \\
\text {-buildings, } \\
\text {-lanes, } \\
\text {-drainage condition, } \\
\text {-water provision, } \\
\text {-water waste management, } \\
\text {-waste management, } \\
\text {-fireproof protection }\end{array}$ & $\begin{array}{l}\text { Used in the } \\
\text { preliminary analysis } \\
\text { related to the } \\
\text { dominant factors that } \\
\text { cause the slum }\end{array}$ & $\begin{array}{l}\text { Physical condition of Kelayan's } \\
\text { riverside and dominant factor } \\
\text { that cause the riverside slum }\end{array}$ \\
\hline
\end{tabular}

For the primary data necessity is conducted the simple randomize sample with the slovin formula and the margin of error to $5 \%$. The family clusters that become the sample is decided by the sub-districts around 442 householders. After it has counted with slovin formula in each of the subdistricts, the number of householders that become the sample is 366 householders. 
This following table is the list of sources and informant also the list of necessity information from the sources and informants.

Tabel 2. Informants list

\begin{tabular}{|c|c|c|c|}
\hline $\begin{array}{l}\text { Technique of } \\
\text { sample }\end{array}$ & Sources/Informants & $\begin{array}{r}\text { Required } \\
\text { Information }\end{array}$ & Data Usage \\
\hline $\begin{array}{l}\text { Simple } \\
\text { Random } \\
\text { Sampling } \\
\text { n=N/N(d) }{ }^{2+1}\end{array}$ & 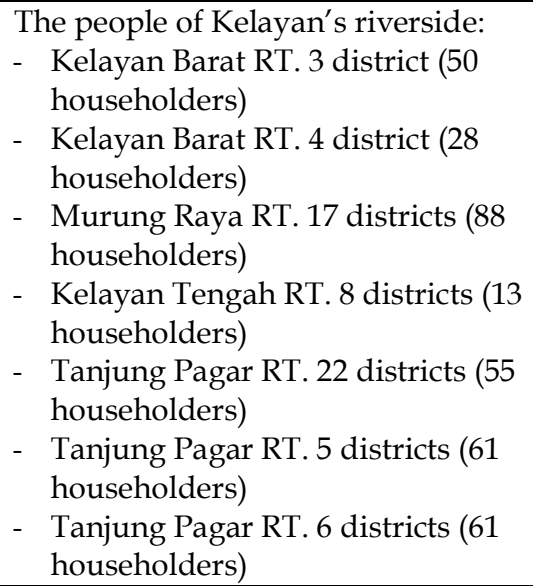 & $\begin{array}{lll}\begin{array}{l}\text { Primary } \\
\text { (variable and }\end{array} & \text { data } \\
\text { variable) } & & \end{array}$ & $\begin{array}{l}\text { To discover the } \\
\text { condition in the field } \\
\text { of every houses on } \\
\text { the riversides. }\end{array}$ \\
\hline
\end{tabular}

The analysis method that is used in this study in quantitative with the case-study approach. Quantitative analysis is used to discover the dominant factors of the Sungai Kelayan's riverside slum area, after conducted the questionnaire then analysed with the scoring in every indicators based on parameters and scored that has been taken from government regulation of PUPR number 2 year 2016. Then, it is discovered that the dominant factors that cause the slum in research location. Based on the sample of the data that has been taken, the result of the analysis that acquired will be tested hypothetically for the proportion in order to figure out the data that has been acquired has already valid and can be used.

\section{RESULT AND DISCUSSION}

\section{Physical Analysis Aspect of the Slum Indicator}

There are several physical indicator aspects, such as the building's regularity, building occupancy's density, the properness of building's occupancy, accessibility to surrounding, environment drainage, drinkable water provision, water sewage management, waste management and fire hazard securement alert. This physical indicator aspects then divided into several categories which carried out the final scores or each of indicators percentages. Scores or percentages of each indicators are used as the score for slum area factors.

\section{Building's Regularity}

Building's Regularity is one of the aspect of physical indicator for slum. The percentages of building's regularity valued as 0 if the building unit hold on the border of the river and it is not face toward the river (does not have two way door accessibility), it does not have the accessibility to the road and it is not face toward the road also stay in waste area/factory waste/high voltage electricity. Here are the result of questionnaire scores toward the aspect of building's regularity in district Kelayan Barat, Kelayang Tengah, Murung Raya and Tanjung Pagar.

Table 3. Buildings Regularity

District Sub-district Amount of $\quad$ Amount of the building


Causal Factors of the Locality Disappearance of Kelayan's Riverside Settlement in Banjarmasin Annisa Yuniar

\begin{tabular}{|c|c|c|c|c|}
\hline & $\begin{array}{l}\text { Number } \\
\text { (RT) }\end{array}$ & Buildings (unit) & $\begin{array}{l}\text { that has the regularity } \\
\text { (unit) }\end{array}$ & $\begin{array}{l}\text { Building's } \\
\text { Regularity }\end{array}$ \\
\hline \multirow[t]{2}{*}{ Kelayan Barat } & 3 & 50 & 0 & 0 \\
\hline & 4 & 28 & 7 & 1.91 \\
\hline Murung Raya & 17 & 88 & 0 & 0 \\
\hline $\begin{array}{l}\text { Kelayan } \\
\text { Tengah }\end{array}$ & 8 & 13 & 7 & 1.91 \\
\hline \multirow{3}{*}{ Tanjung Pagar } & 22 & 55 & 3 & 0.81 \\
\hline & 5 & 61 & 20 & 5.64 \\
\hline & 6 & 71 & 0 & 0 \\
\hline Total & & 366 & 37 & 10.11 \\
\hline
\end{tabular}

From above analysis, the building's regularity lowest point is on $0 \%$ which is RT. 3 Kelayan Barat district, RT. 17 Murung Raya District and RT. 6 Tanjung Pagar disctrict. Hence, the building's regularity score to this riverside settlement is $90 \%$.

\section{Building Occupancy's Density}

Building occupancy's density is the division among the amount of building to the settlement width. In the Rencana Tata Ruang Wilayah (RTRW)/ Spatial-layout plans design of Banjarmasin city, the status of building occupancy's density on the district of Kelayan Barat, Kelayan Tengah, Tanjung Pagar and Murung Raya can be seen in this picture.

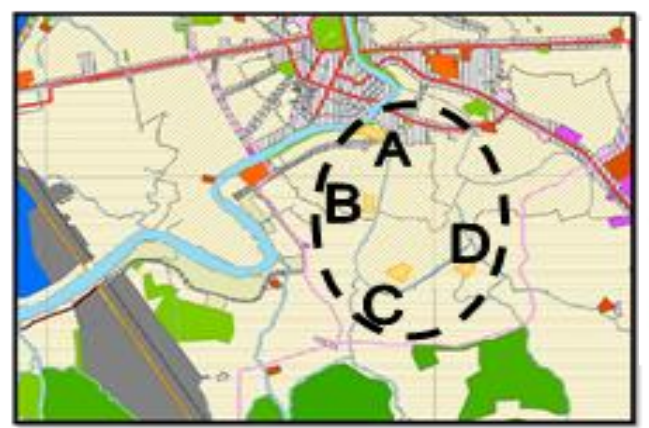

Information:

A. Kelayan Barat district RT. 3 \& 4

B. Kelayan Tengah district RT. 8

C. Murung Raya district RT. 17

D. Tanjung Pagar district RT. 22, 5 \& 6

High Density

Medium Density

Low Density

Figure 2. Building Occupancy's density

From the picture above, the status of building occupancy's density on Kelayan Barat district and Kelayan Tengah district have the status of high density, on Murung Raya district has the status of medium capacity houses, on the Tanjung Pagar district the status of house is low. However, this status is not possibly will stay the same in years as the amount of the building's occupancy will grow according to the amount of population per year.

From the slum area parameter, it can be concluded that the building's density that become the parameter is the building that has disintegrate with the regulation or has the high density such as the buildings that stand in Kelayan Barat district and Kelayang Tengah. The building's density can be seen in this following picture. 

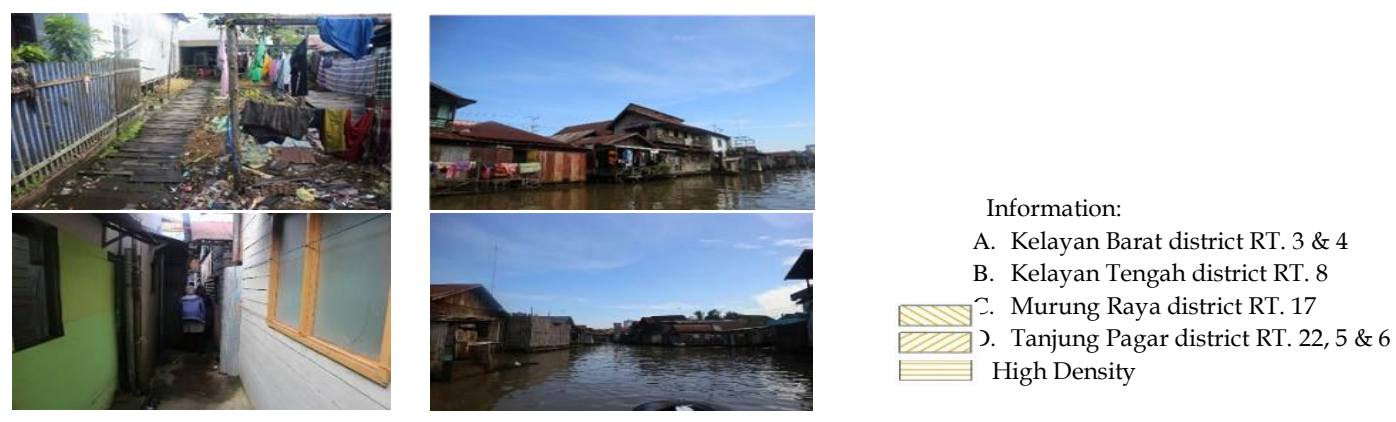

Figure 3. Building Occupancys's Density on Kelayan Riverside

From the pictures above, we can find that the building occupancy's density in every each of the RT slum riverside is slight densed and disorganized. The buildings that stay in the riverside has multiple layers, and in between of this density there is found a small lane access to the river such as pavement made from woods/logs. The highest density of building is located in Kelayan Barat and Kelayan Tengah district with the amount of building in the riverside are 103 units, therefore the total of building occupancy in the research location is 452 units. In conclusion, $22 \%$ of the building occupancy that cover the high density.

\section{The Properness of Building's Occupancy}

The properness of building's occupancy is scored by the width of the building/person whereas the score of properness of this building will scored $100 \%$ if the width of the building's occupancy $\geq 7,2$-meter square/person. The score of properness of bulding's occupancy can be seen in this following table 4 .

Table 4. The properness of Building's Occupancy

\begin{tabular}{ccccc}
\hline District & $\begin{array}{c}\text { Sub- } \\
\text { district } \\
\text { Number } \\
\text { (RT) }\end{array}$ & $\begin{array}{c}\text { Amount } \\
\text { of } \\
\text { Buildings } \\
\text { (unit) }\end{array}$ & $\begin{array}{c}\text { The amount of buildings with } \\
\text { the width of the building's } \\
\text { occupancy/person } \mathbf{2 7 . 2} \\
\text { m2/person) }\end{array}$ & $\begin{array}{c}\text { The } \\
\text { properness of } \\
\text { Building's } \\
\text { score (\%) }\end{array}$ \\
\hline Kelayan Barat & 3 & 50 & 29 & 7.92 \\
\hline Murung Raya & 4 & 28 & 20 & 5.46 \\
\hline Kelayan Tengah & 8 & 88 & 63 & 17.21 \\
\hline Tanjung Pagar & 22 & 13 & 13 & 3.55 \\
\cline { 2 - 5 } & 5 & 55 & 46 & 12.57 \\
\hline Total & 6 & 71 & 43 & 11.75 \\
\hline The & & 366 & 248 & 9.29 \\
\hline
\end{tabular}

The properness of the building's occupancy based from analysis above is showing that $67 \%$ of the building is proper. Therefore, the building that is inhabitable in the riverside settlement is 33\%. If it is seen from the slum parameter, the number of $33 \%$ is hold the value of $25 \%-50 \%$ in the building location that is not proper, so that the score is 1.

\section{Accessibility to Surrounding}

Accessibility to surrounding is scored with two distinguish categories, which are system coverage to the feasible road and the road that is in accordance to the technical requirements. System coverage to the feasible road is scored as $100 \%$ if the length of the road with width of $\geq 1,5$ meters and hardened surface. The system coverage to feasible road that is in accordance with the technical requirements can be seen in this following table. 


\begin{tabular}{|c|c|c|c|c|}
\hline District & $\begin{array}{c}\text { Sub- } \\
\text { district } \\
\text { Number } \\
\text { (RT) }\end{array}$ & $\begin{array}{l}\text { Total Road } \\
\text { Coverage } \\
\text { (meter) }\end{array}$ & $\begin{array}{l}\text { The length of the } \\
\text { road with width } \\
>1.5 \text { meter that } \\
\text { hardened surface } \\
\text { (meter) }\end{array}$ & $\begin{array}{l}\text { System coverage to } \\
\text { feasible road }(\%)\end{array}$ \\
\hline \multirow{2}{*}{ Kelayan Barat } & 3 & 418 & 310 & 8.73 \\
\hline & 4 & 263 & 199 & 5.60 \\
\hline Murung Raya & 17 & 645 & 455 & 12.81 \\
\hline Kelayan Tengah & 8 & 178 & 178 & 5.01 \\
\hline \multirow{3}{*}{ Tanjung Pagar } & 22 & 678 & 535 & 15.07 \\
\hline & 5 & 534 & 312 & 8.79 \\
\hline & 6 & 835 & 432 & 12.17 \\
\hline Total & & 3551 & 2421 & 68.18 \\
\hline
\end{tabular}

In the results of the above analysis, the coverage of the road system that is said to be feasible in Kelayan Barat Kelurahan, Murung Raya, Kelayan Tengah and Tanjung Pagar with a width of more than 1.5 meters and hardened surface is $68 \%$ and for the value of an unfeasible network coverage is equal to $32 \%$. The number shows that the score for one of these aspects is 1 .

\section{Environmental Drainage}

Environmental drainage is obtained from the calculation of the area of inundation areas in settlements and drainage length with conditions that are not damaged / functioning well. In the flooded area can be analyzed from the inundation height, inundation duration, inundation frequency in years and inundation sources. The drainage analysis is obtained from the total drainage length and which is still functioning properly. The results of the analysis can be seen in the following table.

Table 6. Environmental Drainage

\begin{tabular}{ccccc}
\hline District & $\begin{array}{c}\text { Sub- } \\
\text { district } \\
\text { Number } \\
\text { (RT) }\end{array}$ & $\begin{array}{c}\text { Inundation } \\
\text { Height (ha) }\end{array}$ & $\begin{array}{c}\text { Drainage } \\
\text { availability (in the } \\
\text { pavement/primary } \\
\text { drainage) }\end{array}$ & $\begin{array}{c}\text { Percentage of Area } \\
\text { There is no } \\
\text { Inundation in } \\
\text { Settlement (\%) }\end{array}$ \\
\hline Kelayan Barat & 3 & 0 & Available & 100 \\
\cline { 2 - 5 } Murung Raya & 4 & 0 & Available & 100 \\
\hline $\begin{array}{c}\text { Kelayan } \\
\text { Tengah }\end{array}$ & 8 & 0.3 & Available & 71 \\
\hline Tanjung Pagar & 22 & 0 & Available & 100 \\
& 5 & 0 & Available & 100 \\
& 6 & 0 & Available & 100 \\
\hline
\end{tabular}

From the results of the analysis above, almost all slum sub-districts do not have problems with inundation. The subdistricts also have drainage that is on the edge of the road / along the Kelayan A and Teluk Kelayan roads. 


\section{Drinking Water Services}

There are several main sources of water for drinking, bathing and washing running water, running water without the watermeter, drilled-well, protected well, rain water and others. To analyze the score of water needs can be seen from the adequacy of drinking water, bathing, washing throughout the year. The analysis can be seen in the following Table 7.

Table 7. Drinking Water Services

\begin{tabular}{lcccc}
\hline District & $\begin{array}{c}\text { Sub-district } \\
\text { Number } \\
(\mathbf{R T})\end{array}$ & $\begin{array}{c}\text { Amount of } \\
\text { the } \\
\text { Buildings }\end{array}$ & $\begin{array}{c}\text { Air Amount of } \\
\text { people with } \\
\text { accessible water }\end{array}$ & $\begin{array}{c}\text { Accessibility water } \\
\text { score (\%) }\end{array}$ \\
\hline Kelayan Barat & 3 & 50 & 50 & 100 \\
\cline { 2 - 5 } Murung Raya & 4 & 28 & 28 & 100 \\
\hline $\begin{array}{l}\text { Kelayan } \\
\text { Tengah }\end{array}$ & 8 & 88 & 88 & 100 \\
\hline Tanjung Pagar & 22 & 13 & 13 & 100 \\
\cline { 2 - 5 } & 5 & 55 & 55 & 100 \\
\hline Total & 6 & 61 & 61 & 100 \\
\hline
\end{tabular}

From the results of the analysis, all buildings have access to get water. Then, the water access score is 100\% and for RT. 6 67\% of Tanjung Pagar district can access water because they still do not have PDAM's (Local Water Distillation Company) connections. So, the value of households that can access water on the banks of the Kelayan River is $93 \%$. From these results, the drinking water service which is assessed from the access and fulfilment of drinking water needs in riverside settlements has been fulfilled.

\section{Water Sewage Management}

At this stage of the analysis, the assessment is based on toilet facility access and the technical feasibility score of toilet facilities. For access score toilet facilities households, they use their own water closet, public toilets or do not have any water closet. The toilet facility access score will give a value of $100 \%$ if each household has its own toilet. The technical feasibility of toilet facilities is can be seen from the type of toilet used, as well as waste disposal facilities. The technical feasibility score for the toilet facility will be valued $100 \%$ if the type of toilet used is the goose neck type and waste disposal in the form of private / communal septic tank. The results of the analysis can be seen in Table 8 below.

Table 8 Toilet Access Facility

Table 8. Toilet Access Facility

\begin{tabular}{lcccc}
\hline \multicolumn{1}{c}{ District } & $\begin{array}{c}\text { Sub-district } \\
\text { Number } \\
\text { (RT) }\end{array}$ & $\begin{array}{c}\text { Amount } \\
\text { of } \\
\text { Building }\end{array}$ & $\begin{array}{c}\text { Amount of Building that } \\
\text { has toilet }\end{array}$ & $\begin{array}{c}\text { (\%) Toilet Access } \\
\text { Facility Score (\%) }\end{array}$ \\
\hline $\begin{array}{l}\text { Kelayan } \\
\text { Barat }\end{array}$ & 3 & 50 & 33 & 9.02 \\
\hline $\begin{array}{l}\text { Murung } \\
\text { Raya }\end{array}$ & 17 & 28 & 5 & 1.37 \\
\hline $\begin{array}{l}\text { Kelayan } \\
\text { Tengah }\end{array}$ & 8 & 88 & 10 & 24.04 \\
\hline $\begin{array}{l}\text { Tanjung } \\
\text { Pagar }\end{array}$ & 22 & 13 & 48 & 2.73 \\
\cline { 2 - 5 } & 5 & 55 & 49 & 13.11 \\
\hline
\end{tabular}


Causal Factors of the Locality Disappearance of Kelayan's Riverside Settlement in Banjarmasin Annisa Yuniar

\begin{tabular}{lcccc}
\hline & 6 & 71 & 66 & 18.03 \\
\hline Total & 366 & 299 & 81.69
\end{tabular}

To access toilet facilities, the community already has a private toilet with a score of $81 \%$. Only a few houses do not have access to private toilets, they use public toilets that are on the river. From the analysis of the access chapter above, then proceed with the disposal system used. Waste management facilities used to assess the technical feasibility of toilet facilities. The following table water sewage management.

Tabel 9. Water Sewage Management

\begin{tabular}{|c|c|c|c|c|}
\hline District & $\begin{array}{c}\text { Sub- } \\
\text { district } \\
\text { Number } \\
\text { (RT) }\end{array}$ & $\begin{array}{l}\text { Amount of } \\
\text { building }\end{array}$ & $\begin{array}{c}\text { Facility that used (closet type } \\
\text { or septictank) }\end{array}$ & $\begin{array}{c}\text { Technical } \\
\text { feasibility of } \\
\text { toilet facility } \\
(\%)\end{array}$ \\
\hline \multirow[t]{2}{*}{ Kelayan Barat } & 3 & 50 & $\begin{array}{c}\text { Not Water Closet; Not } \\
\text { Septictank }\end{array}$ & 0 \\
\hline & 4 & 28 & $\begin{array}{l}\text { Not Water Closet; Not } \\
\text { Septictank }\end{array}$ & 0 \\
\hline Murung Raya & 17 & 88 & $\begin{array}{l}\text { Used Water Closet; Not } \\
\text { Septictank }\end{array}$ & 0 \\
\hline $\begin{array}{l}\text { Kelayan } \\
\text { Tengah }\end{array}$ & 8 & 13 & Water Closet; Not Septictank & 0 \\
\hline \multirow{3}{*}{$\begin{array}{l}\text { Tanjung } \\
\text { Pagar }\end{array}$} & 22 & 55 & Water Closet; Not Septictank & 0 \\
\hline & 5 & 61 & Water Closet; Not Septictank & 0 \\
\hline & 6 & 71 & Water Closet; Not Septictank & 0 \\
\hline
\end{tabular}

From the analysis results above, the type of toilet used in the RT. 3 and RT. 4 Kelayan Barat district is not a water closet type but a pit privy/latrine system. Whereas, in all slum areas, sewage disposal does not use septic tank, which means the technical feasibility score for toilet facilities is $0 \%$. So the technical feasibility score for toilet facilities in the slums of the Kelayan River is $0 \%$. To sum up, the water sewage management score does not match the technical requirements is $100 \%$ so the parameter assessment is 5 .

\section{Waste Management}

At this stage of the analysis, considerations are based on the disposal of household waste and the frequency of transporting garbage from the house to the landfill station. For household rubbish disposal, there are several criteria, namely private rubbish bins, communal rubbish bins, dumped into pits / burned, thrown into empty land / roads and thrown into rivers / drainage sewer. Whereas the transportation of waste from the house to the landfill station is assessed based on the frequency of disposal every week. The score for household waste management will be $0 \%$ if the frequency of transporting waste from home to landfill station is $<1 \mathrm{x}$ a week. The results of the analysis can be seen in the following Table 10.

Table 10. Waste Management

\begin{tabular}{|c|c|c|c|c|}
\hline District & $\begin{array}{c}\text { Sub- } \\
\text { district } \\
\text { Number } \\
\text { (RT) }\end{array}$ & $\begin{array}{c}\text { Household waste } \\
\text { disposal }\end{array}$ & $\begin{array}{l}\text { transportation of waste } \\
\text { from the house to the } \\
\text { landfill station }\end{array}$ & $\begin{array}{l}\text { Household } \\
\text { Waste } \\
\text { Management } \\
\text { Score (\%) }\end{array}$ \\
\hline
\end{tabular}


LOCAL WISDOM, Vol. 12 No. 2 July 2020

Local Wisdom Scientific Online Journal

\begin{tabular}{ccccc}
\hline $\begin{array}{c}\text { Kelayan } \\
\text { Barat }\end{array}$ & 3 & River & - & 0 \\
\cline { 2 - 5 } $\begin{array}{c}\text { Murung } \\
\text { Raya }\end{array}$ & 17 & River & $<1 \times$ A week & 0 \\
\hline $\begin{array}{c}\text { Kelayan } \\
\text { Tengah }\end{array}$ & 8 & $\begin{array}{c}\text { Pandfill } \\
\text { bin }\end{array}$ & $>2 \times$ A week & 100 \\
\hline $\begin{array}{c}\text { Tanjung } \\
\text { Pagar }\end{array}$ & 22 & Incinerated & $<1 \times$ A week & 0 \\
& 5 & Incinerated & - & 0 \\
\hline & 6 & Incinerated & - & 0 \\
\hline
\end{tabular}

From the analysis results above, it can be seen only RT. 8 Kelayan Tengah district, which throws more than twice as much garbage to the nearest landfill station. Hence, out of 366 householders only 13 householderss or as much as $4 \%$ dispose of their waste in landfill station more than $2 x$ in a week. From these results it can be concluded that $96 \%$ of the management of waste bins is not in accordance with technical requirements.

\section{Fire hazard securement alert}

For the analysis of fire safety, the consideration is only in the form of fire protection infrastructure / facilities in each subdistricts. Scores received by fire prevention facilities / infrastructure can be seen in the following Table 11.

Table 11. Fire hazard securement alert

\begin{tabular}{cccc}
\hline District & $\begin{array}{c}\text { Sub-district } \\
\text { Number (RT) }\end{array}$ & $\begin{array}{c}\text { Fire prevention } \\
\text { facilities }\end{array}$ & $\begin{array}{c}\text { Infrastructure of fire } \\
\text { prevention station }\end{array}$ \\
\hline Kelayan Barat & 3 & None & Available \\
\cline { 2 - 4 } Murung Raya & 4 & None & Available \\
\hline $\begin{array}{c}\text { Kelayan } \\
\text { Tengah }\end{array}$ & 17 & Available & Available \\
\hline Tanjung Pagar & 8 & None & Available \\
\cline { 2 - 4 } & 22 & Available & Available \\
& 5 & None & Available \\
& 6 & None & Available
\end{tabular}

From the results analysis above, fire protection facilities such as fire extinguisher and pump cars are not available, but in the city of Banjarmasin generally already have fire trucks in every village. For infrastructure such as the availability of water and fire extinguishers, it is available because it is located in the riverbank area. So as for the protection of fire hazards only the facility that need to be completed in each subdistricts.

\section{Scoring Factors}

At this stage, the analysis is carried out by scoring according to the parameters set above. The results of the analysis of dominant factors can be seen in Table 12 below.

Table 12. Dominant Factors of the Kelayan Riverside Slum Area

District Parameter Score

$\begin{array}{lll}\text { Kelayan Barat, Kelayan } & 90 \% \text { of buildings on site have no regularity } & 3 \\ \begin{array}{c}\text { Tengah, Murung Raya, } \\ \text { Tanjung Pagar }\end{array} & \begin{array}{l}22 \% \text { of buildings have a density that is not } \\ \text { according to regulations }\end{array} & 1\end{array}$




\begin{tabular}{|c|c|}
\hline $\begin{array}{l}33 \% \text { of buildings on the location did not meet } \\
\text { the eligibility requirements of occupancy } \\
\text { buildings }\end{array}$ & 1 \\
\hline $32 \%$ of the system coverage area is not feasible & 1 \\
\hline $\begin{array}{l}0 \% \text { of the area is not available drainage } \\
\text { environment }\end{array}$ & 0 \\
\hline $\begin{array}{l}7 \% \text { of the population cannot access drinking } \\
\text { water and the minimum drinking water needs } \\
\text { are not met }\end{array}$ & 0 \\
\hline $\begin{array}{l}100 \% \text { water sewage management does not } \\
\text { comply with technical requirements }\end{array}$ & 3 \\
\hline $\begin{array}{l}96 \% \text { of household waste management does not } \\
\text { comply with technical requirements }\end{array}$ & 3 \\
\hline $\begin{array}{l}0 \% \text { unavailability of fire protection facilities / } \\
\text { infrastructure }\end{array}$ & 0 \\
\hline
\end{tabular}

Scores: Score 0: Excellent, Score 1: Good, Score 2: Fair, Score 3: Poor

From the results of the overall analysis, the dominant factors of slum areas based on physical aspects of slum indicators on the Kelayan Riversides are the regularity of buildings, water sewage management and waste management. After finding the dominant factor, proceed with the hypothesis test for proportions. At this stage, the results of the above factors are hypothesized for proportions. There are five indicators tested in the hypothesis, namely the regularity of buildings, the feasibility of occupancy's buildings, access to drinking water, access to toilet facilities and waste management. It is known as follows:

$\mathrm{n}=366$ householder

Degree of Freedom $(\mathrm{DF})=5 \%, 2$ side testing, critical point $\mathrm{Z \sigma} / 2=1.96$

$\mathrm{H} 0$ rejected on $\mathrm{z}<-1,96$ or $>1.96$

a.Building Regularity

The irregularity of buildings in the Kelayan Riverside slum area is $90 \%$, then it can be calculated in the formula below.

H0: $p=92 \%$ H1: $p \neq 92 \%$

$$
\begin{aligned}
z & =\frac{\left(\bar{p}-p_{0}\right)}{\sqrt{p_{0} q / n}} \\
& =(0.9-0.92) / \sqrt{ } 0.92 \times 0.08 / 366 \\
& =-0.02 / 0.014 \\
& =-1.42, z>-1.96, \text { H0 accepted. }
\end{aligned}
$$

b. The properness of building's occupancy

The properness of building occupancy in the Kelayan Riverside slum area is $67 \%$ or $33 \%$ of the building is not feasible, so it can be calculated in the formula below.

H0: $p=37 \%$ H1: $p \neq 37 \%$

$$
\begin{aligned}
z & =\frac{\left(\bar{p}-p_{0}\right)}{\sqrt{p_{0}} q / n} \\
& =(0.33-0.37) / \sqrt{ } 0.37 \times 0.63 / 366 \\
& =-0.04 / 0.025 \\
& =-1.6, z>-1.96, \text { H0 accepted. }
\end{aligned}
$$

c. Drinkwater accessibility 
People who cannot access drinking water in the slums of the Kelayan Riverside are 7\%, counted on the formula below.

$$
\begin{aligned}
& \text { H0: } p=9 \% \quad H 1: p \neq 9 \% \\
& \begin{aligned}
z & =\frac{\left(\bar{p}-p_{0}\right)}{\sqrt{p_{0}} q / n} \\
& =(0.07-0.09) / \sqrt{ } 0.09 \times 0.81 / 366 \\
& =-0.02 / 0.014 \\
& =-1.42, z>-1.96, \text { H0 accepted. }
\end{aligned}
\end{aligned}
$$

\section{d. Toilet Facility Access}

Access to toilet facilities in the Kelayan Riverside slum area by $81 \%$ so that it can be calculated in the formula below.

$$
\begin{aligned}
& \text { H0: } p=84 \% \text { H1: } p \neq 84 \% \\
& \begin{aligned}
z & =\frac{\left(\bar{p}-p_{0}\right)}{\sqrt{p_{0} q / n}} \\
& =(0.81-0.84) / \sqrt{ } 0.84 \times 0.16 / 366 \\
& =-0.03 / 0.019 \\
& =-1.57, z<-1.96, \text { H0 accepted. }
\end{aligned}
\end{aligned}
$$

\begin{tabular}{|c|c|}
\hline Parameter According to the Sample & Parameter after hypotesys testing \\
\hline $90 \%$ of buildings on site have no regularity & $\begin{array}{l}92 \% \text { of buildings on site have no } \\
\text { regularity }\end{array}$ \\
\hline $\begin{array}{l}33 \% \text { of buildings on the location did not meet } \\
\text { the eligibility requirements of occupancy } \\
\text { buildings }\end{array}$ & $\begin{array}{l}\text { 37\% of buildings on the location did not } \\
\text { meet the eligibility requirements of } \\
\text { occupancy buildings }\end{array}$ \\
\hline $\begin{array}{c}7 \% \text { of the population cannot access } \\
\text { drinking water and the minimum drinking } \\
\text { water needs are not met }\end{array}$ & $\begin{array}{c}9 \% \text { of the population cannot access } \\
\text { drinking water and the minimum drinking } \\
\text { water needs are not met }\end{array}$ \\
\hline $\begin{array}{l}96 \% \text { of household waste management does } \\
\text { not comply with technical requirements }\end{array}$ & $\begin{array}{c}97 \% \text { of household waste management } \\
\text { does not comply with technical requirements }\end{array}$ \\
\hline
\end{tabular}

\section{e.Waste management}

Waste management in the Kelayan Riverside slum area which is not in accordance with the technical requirements of $96 \%$ so it can be calculated in the formula below.

$$
\begin{aligned}
& \text { H0: } p=97 \% \text { H1: } p \neq 97 \% \\
& \begin{aligned}
z & =\frac{\left(\bar{p}-p_{0}\right)}{\sqrt{p_{0} q / n}} \\
& =(0.96-0.97) / \sqrt{ } 0.97 \times 0.03 / 366 \\
& =-0.01 / 8.91 \\
& =-1.12, z>-1.96, \text { H0 accepted. }
\end{aligned}
\end{aligned}
$$

Finally, from the results of the hypothesis test analysis above it can be seen that the closest value can be seen in the following table.

Table 13. Analysis Results After the Hypothesis Test

\section{CONCLUSION}

The conclusions obtained from the results of this study are the problems that occur in slums along the riverside with the category of heavy slums, medium slums and mild slums are the irregularity of buildings, waste management and water sewage that pollutes the river. With the similarity of problems in the slums of the Kelayan riverside, although 
different categories prove that the Kelayan riverside has the same slum characteristics along the river. This factor causes losing locality of Kelayan riverside settlement. These slum factors are the cause of the loss of the locality of Banjarmasin river banks. The river, which was once the main water source, is now polluted because it is a landfill and household waste. In addition, the river which was once the main transportation route, is now becoming increasingly narrow due to the irregularity of buildings built by the banks of the bank itself.

\section{References}

Afdholy, A., R. (2019). Architectural Style of Riverside Settlements in Banjarmasin City. Local Wisdom Scientific Online Journal. 11 (2):121-131.

Badan Pusat Statistik, (2016). Statistik Daerah Kecamatan Banjarmasin Selatan.

Basri, H., et al. (2010). Model Penanganan Permukiman Kumuh Studi Kasus Permukiman Kumuh Kelurahan Pontap Kecamatan Wara Timur Kota Palopo. Seminar Nasional Perumahan Permukiman dalam Pembangunan Kota, Maret 2010.

Dahliani. (2012). Konsep Pengolahan Tapak Permukiman di Lahan Rawa Banjarmasin. Lanting Journal of Architecture. 1 (2): 96 -105.

Hamidah N., et al. (2016). Analisis Permukiman Tepian Sungai yang Berkelanjutan Kasus Permukiman Tepian Sungai Kahayan Kota Palangkaraya. Seminar Inersia, Volume XII Nomor 1, Mei 2016.

Heryati. (2008). Identifikasi dan Penanganan Kawasan Kumuh Kota Gorontalo. JURNAL ICHSAN GORONTALO. 3 (4): 1-29.

Imammuddin, M. (2016). Reuse Air Pada Instalasi Pengolahan Air Limbah (IPAL) Guna Mengurangi Daya Rusak Air di UPT Puskesmas Rawat Inap Ajibata Sumatera Utara. Jurnal Konstruksia, Volume 7 Nomor 2, April 2016.

Mentayani I. (2016). Identitas Keruangan Tepian Sungai dan Perubahannya pada Permukiman Vernakular di Banjarmasin. Seminar Nasional-Semesta Arsitektur Nusantara 4, 17-18 November 2016.

Mentayani I., et al. (2009). Aspek-Aspek Tipomorfologi Permukiman Tepi Sungai Kasus: Permukiman Tepian Sungai di Kota Banjarmasin.

Walikota Banjarmasin. (2013). Peraturan Daerah Nomor 5 Tahun 2013 Tentang Rencana Tata Ruang Wilayah (RTRW) Kota Banjarmasin Tahun 2013-2032.

Walikota Banjarmasin. (2015). Surat Keputusan Nomor 460 Tahun 2015 Tentang Penetapan Lokasi Permukiman Kumuh Kota Banjarmasin. 